European Journal of Accounting, Auditing and Finance Research

Vol.8, No.4, pp.121-148, April 2020

Published by ECRTD-UK

Print ISSN: 2053-4086(Print),

Online ISSN: 2053-4094(Online)

\title{
DIFFERENCES OF ENVIRONMENTAL DISCLOSURE QUALITY VIA DIFFERENT REPORTING MEDIA: CASE OF OIL AND GAS COMPANIES IN DEVELOPING COUNTRIES
}

\author{
Dr. Abdullah Hamoud Ismail* Dr. Kamal Al Nakib** \\ Dr. Abdulqawi Ahmed Hezabr*** Dr. Faiza Moammed Al-Msni**** \\ * Assistant Professor of Business School, Lebanese International University, Sana`a, Yemen, \\ Tel: 00967-712-757-209,E-mail: a_h_ismail@yahoo.com (corresponding author) \\ ** Associate Professor of Accounting Department, College of Administrative \& Financial \\ Science, Knowledge University, Erbil, Iraq, Tel: 009647501149312, \\ E-mail: Kamal.alnakib@knu.edu.iq \\ *** Associate Professor of Accounting and Finance Department, Applied Science University, \\ Bahrain, Tel: 0097316036193, E-mail: abdulqawi.Hezabr@asu.edu.bh \\ **** Assistant Professor of Accounting Department, Sana'a University, Sana'a Yemen, Tel: \\ 00967-1-564676,E-mail:faizaalmsni@yahoo.com
}

\begin{abstract}
This study aims to investigate whether there is any significant difference between different reporting mediums (namely, annual report, stand-alone reports, and corporate homepages) regarding their environmental disclosure quality. Using content analysis, an index and scoring scheme were applied to the annual reports, stand-alone reports and corporate homepages of a sample of 116 oil and gas companies in 19 developing countries. The results of this study indicate great variations in the disclosure quality in different reporting media. The stand-alone reports have greater quality than annual reports and corporate homepages in communicating environmental information. The study has implications in enhancing the understanding of environmental disclosure practices of oil and gas companies in developing countries. The study also provided an insight into the differences between disclosures in different reporting mediums, which in turn will facilitate the selection of reporting medium/s of environmental information that can be relied upon.
\end{abstract}

KEYWORDS: environmental disclosure quality, reporting media, oil and gas industry, developing countries

\section{INTRODUCTION}

Global warming and climate change have become important social issues of international concern (Alrazi, De Villiers and Van Staden, 2016). The use of natural resources and continuous emissions of greenhouse gases by industries around the world are on increase, and awareness towards environmental issues has increased and become a key concern for different stakeholders (Okafor, 2018; Prasad, Mishra and Kalro, 2016). Nowadays, business organizations are under increasing pressure from the governmental and non-governmental organizations to be environmentally sustainable (Mahmood, Ahmad, Ali and Ejaz, 2017). 
Print ISSN: 2053-4086(Print),

Online ISSN: 2053-4094(Online)

Thus, in a bid to gain legitimacy, most organizations have recognized the relevance of their environment to their businesses and the need to safeguard it (Welbeck, Owusu, Bekoe and Kusi, 2017). It was argued that an organization should consider all environmental issues relevant to its operations and take a strategic approach to improve its environmental performance (Susanto and Mulyono, 2017).

With the increasing global concern for the environment, the pressure on corporate environmental disclosure is increasing from various stakeholders (Ioannou and Serafeim, 2017; Prasad, et al., 2016; Wei and Wang, 2016), and environmental disclosure occupies a significant place within a firm's strategy (Ismail, 2017). Environmental disclosure is a successful strategy to make a corporation more acceptable in society's eyes (Bani-Khalid, Kouhy and Hassan, 2017). Thus, to respond to pressure from stakeholders, companies have to provide information about their activities in preserving the environment. Environmental disclosure can help corporations to establish a good public image and also to improve their economic performance (Yin and Wang, 2017).

According to Islam, Hosen and Islam (2005) environmental disclosure is "an umbrella term that describes the various means by which companies disclose information on their environmental activities". Lodhia (2006) has defined the corporate environmental reporting as "a process through which "companies often disclose environmental information to their stakeholders to provide evidence that they are accountable for their activities and the resultant impact on the environment". Environmental disclosure is also defined by Kuo and Chen (2013) as "a set of information items that relate to a firm's past, current, and future environmental management activities and performance" (p. 1467), and by Yusoff, Othman and Yatim (2013) as "any written passage about company's environmental issue and activity" (p. 1720). According to Cormier and Gomez-Gutierrez (2018), environmental disclosure refers to "all corporate disclosures concerning their responsibility against the natural environment". For the purpose of this study, environmental disclosure is defined as a process of communicating the information on environmental issues through various reporting mediums including; annual report (AN), separate stand-alone environmental-related reports (STAN), and corporate homepage of Internet (HOM).

The growth in research focus on environmental disclosure issues has been borne out of the growing concern over the harmful effect of business activities on the environment (Welbeck et al., 2017). Several earlier studies revealed that firms, especially those operating in environmentally sensitive industries, disclose social and environmental information to promote/ enhance their images and reputations and in turn for the legitimization of their societal existence (e.g. Deegan, Rankin, \& Tobin 2002; Kuo and Chen, 2013; Patten, 1992; Yusoff and Lehman, 2009). Thus, social and environmental disclosure is considered a tool which could help companies to influence society`s perceptions toward corporate operations 
(Haji, 2013).

However, most of previous studies have been restricted to the developed world and very few studies, to date, have examined the actual environmental reporting practices of firms within the context of developing countries (Welbeck et al., 2017). Moreover, the majority of prior environmental disclosure studies have focused on the quantity of disclosure but scant attention has given to disclosure quality (Cuesta and Valor, 2013). Disclosure quality measure enables to evaluate meaning and importance of disclosure, rather than just the volume (Walden and Schwartz, 1997). Disclosure quality can have a significant influence on the quality of the decisions made by stakeholders (Brink, Haines, Owen, Smith, \& Whitaker, 1997). Hasseldine, Salama and Toms (2005) suggested that environmental disclosure quality as opposed to just quantity has a significant impact on the development of environmental reputation among stakeholder groups of investors and executives. The quality of the environmental disclosure can be seen as a key value for companies, and many benefits could be provided if the company released high quality environmental information (Rattanaphaphtham and Kunsrison, 2011). It is recognized that the quality of environmental disclosure (as compared to its quantity) is important (Sulaiman, Abdullahb and Fatima, 2014).

The literature also points out that the majority of previous studies concerned with environmental disclosure focused on a sole media of reporting (often annual report), while, a few studies have covered several reporting mediums. It is argued that most often annual reports do not adequately capture environmental performance, hence leading us to believe that whatever performance these companies are boasting of isn't the true one (Sahore and Verma, 2017). Very few studies have compared between different mediums of reporting. However, no study has compared different reporting mediums of environmental information regarding their disclosure quality.

In terms of industry, the oil and gas industry is among the industries with the greatest impacts on the environment (International Energy Agency [IEA], 2015). The overall environmental effects of the petroleum operations on the natural environment are very high, as the operations of this industry cause air pollutions and responsible for the waste they emit in the sea which is very disastrous for the life under sea (Mughal, 2014). Several vital environmental incidents that occurred in the oil and gas industry worldwide have revealed the significant impact of this industry's activities on the environment (Hossain, Islam and Andrew, 2006), raising public awareness (Frynas, 2009; Sustainability \& UNPE, 1999).

Despite this, there are a few studies examined environmental disclosure in oil and gas industry (cf. Barr, 2007; Dibia and Onwuchekwa, 2015; Eljayash, James and Kong, 2012; Eljayash, Kavanagh and Kong, 2013; Heflin and Wallace, 2014; Oba and Fodio, 2012a; Patten, 1992; Sustainability Ltd. \& UNEP, 1999). However, the adverse effects of oil and gas 
companies are greater in the developing countries (Abdalla and Siti-Nabiha, 2015). With exception of Oba and Fodio (2012b) and Eljayash et al. (2012) there are no studies did analyzed the quality of environmental disclosure in oil and gas industry. However, these two studies are suffering from some limitations, such as limiting themselves to annual reports and the samples are small.. Hence, this study intends to fill this knowledge gap by examining the quality of environmental disclosure made by oil and gas companies in developing countries.

In sum, in the literature, a few studies have combined more than one reporting medium. However, most of the studies that covered mediums other than annual reports did not analyze the other mediums separately; instead, they were analyzed as additional sources (Sapkauskiene and Leitoniene, 2014). Thus, there appears to be a gap in the literature in respect of environmental disclosure studies that compare different reporting mediums, as there are very few previous studies that have compared environmental disclosures made in various reporting mediums. Moreover, no study has compared between different media based on the quality of disclosure. In this regards, previous studies have suggested comparison between different reporting mediums. For example, Zeghal and Ahmed (1990) recommended that future research work covers other mediums, and to answer question such as: "How are disclosures through annual reports compared with other mediums?". Belal and Momin (2009) recommended researchers to answer the question: "Are there any significant differences between different mediums used for CSR in emerging economies?". Vuorela (2014) suggested conducting a comparison study of environmental disclosures in different reporting media such as annual reports and corporate websites. This present study attempts to fill this gap in literature.

The rest of the paper is structured as follows, section 2 contains literature review. Section 3 explains the research methodology. Section 4 presents the results and discussions of empirical analyses. Section 5 contains concluding remarks, implications of the study while section 6 contains limitations of the study and suggestions for further research.

\section{LITERATURE REVIEW}

\section{Media for Environmental Disclosure}

There are various mediums for disclosing environmental information including: annual reports, supplements to the annual reports or generated at interim dates, reports on the environment and society, sustainability reports, activities advertisements and articles, environmental brochure or corporate brochure, booklets or leaflets on the environmental performance addressing the company's activities and products labeling to promote environmental and other concerns, newspaper or magazine, CD reports, television and radio, video tapes, and websites. Companies may also disclose environmental information via seminars or symposium, as well as in meeting with residents (Mughal, 2014; Guo, 2005; Tilt, 
European Journal of Accounting, Auditing and Finance Research

Vol.8, No.4, pp.121-148, April 2020

Published by ECRTD-UK

Print ISSN: 2053-4086(Print),

Online ISSN: 2053-4094(Online)

1994; Williams and Pei, 1999; Zeghal and Ahmed, 1990).

Although social and environmental disclosure may be done via different media, majority of studies have only focused on the annual reports of organizations (Buhr, 1994; Gray, Javad, Power and Sinclair, 2001; Zeghal and Ahmed, 1990). This is confirmed by reviewing pertinent prior literature (cf. Adams, Hill and Roberts, 1998; Eljayash et al., 2012; Eljayash et al., 2013; Gamble, Hsu, Jackson and Tollerson, 1996; Oba and Fodio, 2012a,b; Sulaiman et al., 2014; Wiseman, 1982).

However, many authors pointed out that annual report is not the only medium that could be used for environmental disclosure and offered this as a limitation of their research. For example, Zeghal and Ahmed (1990) pointed out that firms use other mediums along with annual reports to disclose their social and environmental information. Some studies cover, in addition to annual reports, separate reports such as environmental reports (e.g. Buhr \& Freedman, 2001). Other studies (such as Adams and Frost, 2004; and Jones, Alabaster \& Hetherington, 1999) examined environmental disclosure on internet whereas some others covered other media for environmental disclosure; for example, Zeghal and Ahmed (1990) examined corporate brochures and advertisements along with annual reports. Cormier, Ledoux and Magnan (2009) combined between three disclosure vehicles, namely, paper-based environmental disclosure, web-based environmental disclosure and press releases environmental disclosure. A recent study of Wong and Wong (2015) has combined between three reporting media, particularly, annual reports, sustainability reports and websites of the top three Hong Kong`s companies. The study aimed to examine the practices of corporate social responsibility but not disclosure.

In practice, while a company may prefer a certain vehicle for disclosing environmental information, it still does not limit its self to use one vehicle of disclosure, rather, companies use different media to disclose their environmental information. However, there are increasing numbers of companies who are disclosing their environmental information through separate environmental, social and sustainability reports (Jose and Lee, 2007). In spite of a growing trend toward publishing stand-alone reports, prior literature did not pay much attention to these reports. It is important to give more attention to these reports (Hassan, 2010).

Moreover, users of company's environmental information may not be satisfied by reviewing one type of report containing environmental information (annual report, environmental or social or sustainability report). A company may present a particular type of environmental information on a certain medium, while at the same time it presents another type of environmental information in another medium. In other words, adequate information may not be available in one report, but different reports may, cumulatively, contain quite adequate 
information.

It was argued that specific concentration on annual reports may lead to an incomplete picture of practices of disclosure (Roberts, 1992). Zeghal and Ahmed (1990) claimed that, confining the study to annual reports may provide only a portion of the overall picture of reporting. Several studies (e.g. Skillius and Wenberg, 1998; Wheeler and Elkington, 2001) emphasis on the notion that different media is disseminated to different stakeholders. Razeed, Tower, Hancock and Taplin (2004) demonstrated that various communication channels are required and not just one report.

Moreover, according to Tilt (2001a), no evidence showing that the annual report is the most suitable medium for environmental disclosure. Alias (2001) argued that it is the limitation of study that restricts annual reports to investigate environmental disclosure, because companies may disclose their environmental information through other media. Buhr and Freedman (2001) contended that, in instances where companies generate environmental reports, it is more likely that little information will be found in their annual reports. Islam et al. (2005) suggested that, separate environmental reports published by the company (if any) could be investigated.

In short, while, focusing on a certain media of reporting for the examination of environmental disclosure practices may lead to unclear, imprecise and incomplete picture of the actual state of environmental disclosure practices (Alias, 2001; Buhr, 1994; Buhr \& Freedman, 2001; Roberts, 1992; Silva, 2008; Unerman, 2000; Zeghal \& Ahmed, 1990), practically, capturing all communications in different reporting mediums of a company may be problematic (Zeghal \& Ahmed, 1990). Supporting this, Silva (2008) argued that a more extensive emphasis of environmental disclosure is called for, but it is difficult for a researcher to identify all sources of company communication. Therefore, this study encapsulates the main media for environmental disclosure. The main vehicles of disclosing corporate responsibility information (including environmental information) in public domain are annual reports, corporate environmental/ responsibility or sustainability reports, and company websites (KPMG, 2008). For a detailed account, these environmental disclosure media are highlighted in the following paragraphs.

\section{Annual Reports}

Annual reports are the main media companies use to communicate their information to various external users and considered as the most important source of information about a company (Haji, 2013). In the context of environmental disclosure, corporate annual reports are recognized as the main resource for environmental data (Deegan and Rankin, 1997; Haji, 2013; Tilt, 1994; Wiseman, 1982): 
Gray and Bebbington (2001) stated that, it is essential that environmental issues are given substantial attention in the annual report. However, despite the fact that it becomes apparent that companies are providing environmental disclosures in regulatory disclosure documents outside the annual reports (Buhr, 1994), annual reports are still keeping their domination on all.

\section{Stand-alone Reports}

As mentioned earlier, companies previously used to employ annual reports to disclose environmental information. Companies have changed how they report their environmental information, as in the mid-1990s stand-alone environmental reports have emerged and occupied significant place in the realm of environmental reporting (Campbell, 2003). Stand-alone reports are separate reports -from the annual report- dealing with environmental and social issues, and are often referred to as environmental reports, corporate social responsibility reports, social and environmental reports, sustainability reports, triple bottom line reports, or health, safety and environment reports (Hooks and van Staden, 2011; Silva, 2008).

A series of triennial surveys conducted by KPMG that was initiated in 1993 show increasing number of companies publishing separate environmental, social and sustainability reports. The 1993, 1996, 1999, 2002, 2005 and 2008 KPMG`s surveys show that, only minority of companies (15\%) published separate environmental-related reports in 1993, and this percentage has increased to $17 \%$ in the 1996 survey. This increasing trend continued, as the 1999 survey indicated that $35 \%$ of covered companies had published separate environmental-related reports and this number had risen to $45 \%$ in the 2002 sustainability survey, 52\% in the 2005 survey, and $79 \%$ in the 2008 survey (KPMG, 1993, 1996, 1999, 2002, 2005, and 2008). Tilt (2001b) suggests that other than annual report, most likely medium may be used for environmental disclosure is stand-alone environmental report.

Currently, publishing stand-alone environmental-related reports (i.e. environmental report, social responsibility report, sustainability report) is a common practice across industry and across country. Industrially, in oil and gas context, most major companies presently draw up corporate responsibility or sustainability reports that highlight the manner in which they are addressing the stakeholders' environmental and social concerns. Geographically, in many parts of the world the tendency of the companies to produce separate social and environmental reports is increasing (Ramdhony, Padachi \& Giroffle, 2010).

\section{Internet Homepages}

As the World Wide Web (WWW) grows and the numbers of users of this medium are rapidly increasing as organizations are using the internet to advertise and also to report. Consequently, there has been an explosion of reporting, including environmental reporting, through the 
internet (Gray and Bebbington, 2001). In recent years, advances in technology and the ongoing sincrease in Internet access has resulted in the corresponding increase in web use as a reporting medium (Islam et al., 2005). Moreover, concern over ethical social and environmental performance has increased with the relevant information being widely publicized on the internet (Adams, 2002). Websites are alternative media to disseminate environmental, social and sustainability information (Joseph, Pilcher and Taplin, 2014; Lodhia, Jacobs and Park, 2012). Thus, the popularity of the internet has encouraged companies to use this medium for environmental disclosure (Jones, Alabaster and Walton, 1998), and it became a common to see sections on corporate websites dealing with environmental and social issues (Hooks and van Staden, 2011).

The most obvious advantages of internet-based environmental reporting are (Gray and Bebbington, 2001; Jenkins and Yakovleva, 2006; Yusoff et al., 2013): 1) internet is universal access communication channel, 2) internet is better able to communicate with a larger and more divers stakeholders, as by using internet reporting, companies reach a more diverse audience, 3) internet-based environmental reports can be updated easily by the reporting organization, 4) timelines and updating of data, as data can be obtained when required, 5) reduced resource use and costs (for preparer), and 6) users can engage in feedback and firms can effectively keep abreast of respondents' information which helps to develop broader corporate-stakeholders relationships.

Today, in the environment of characterized by both globalization and liberalization, timely information is called for to help users reach effective decisions. The most appropriate tool ensures that information is timely available for external users is internet technology (Al-Arussi, Selamat and Hanefah, 2009). Thus, the internet has become invaluable for company disclosure of information, so examining the corporate web pages for social responsibility information has become as crucial as exploring annual reports (Branco and Rodrigues, 2008).

A major portion of environmental disclosure literature has mainly concentrated on the classical print medium for disclosure (Lodhia, 2005), whilst, the internet has become an increasingly important medium of information disclosure (Kotler \& Lee, 2005), and its use and importance are increasing for different groups of stakeholders (Adams and Frost, 2004). So inclusion of internet as a medium of disclosure in a study concerning environmental disclosure makes the study inevitable. Therefore, in addition to annual reports and stand-alone reports, this study covers environmental-related sections on corporate homepages.

\section{Differences of Environmental Disclosure Quality via Different Reporting Media}

Where do organizations report their environmental information? In this regard, there is little 
Print ISSN: 2053-4086(Print),

Online ISSN: 2053-4094(Online)

debate regarding the suitable place for disclosing financial information while on the other hand, reporting of social and environmental issues is more debatable (Tilt, 2001a). The relative importance of the various environmental reporting mediums has been debated in the literature.

Within prior literature, locations of environmental and social disclosure have not been given attention that it deserves. Although some studies considered the location of disclosure, they discussed and analyzed this dimension within one medium of disclosure, namely, annual report (cf. Manasseh, 2004; Teoh and Thong, 1984). It is believed that ignoring such dimension altogether will cause losing part of the richness of any corporate social disclosure practices (Manasseh, 2004). So, the present study considers the location of disclosure across disclosure media.

Quality of reporting has been contended to significantly influence the decision quality of stakeholders (Brink et al., 1997) and effective reporting should hence facilitate stakeholders' informed decisions that are consistent with their interests (Barr, 2007). So, it can be argued that better source of information depends on the media's higher level of quality. Having this in mind, companies use different kinds of media to disclose their environmental information, and based on findings of some previous studies (for example, Buhr, 1994; Zeghal and Ahmed, 1990) different environmental reporting vehicles send different messages. Thus, users of company's environmental information should not rely on a single source of information, but different vehicles of reporting should be reviewed. On the other hand, a review of all media used by a company for its environmental information is difficult and time consuming for readers. So, for information users it is important to know which medium/s is/are better to be relied on to help in decision making.

According to Mitchell, Percy and McKinlay (2006), while audited information is viewed more credibly, non-audited sections are likely to contain more environmental information. In the absence of mandatory requirements, and because disclosure in audited sections requires additional cost of ensuring compliance with the laws and regulations, companies would rather that their environmental disclosure be non-audited and they are willing to provide more environmental disclosures in those sections (Mitchell, et al., 2006). Similarly, across disclosure vehicles, among several environmental disclosure mediums, only annual report is required to be audited, and thus it is expected that companies would rather their environmental disclosure be non-audited and they are considered to be willing to provide more environmental disclosures in non-audited reports, including environmental report, social report, sustainability report and corporate website. It has been accepted that other disclosure methods may be utilized by companies and that the least amount of the corporate social reporting of the company may be included in the published annual reports (Unerman, 2000). 
However, prior research showed variety between companies in using different disclosure media to communicate their environmental and social information. For example, KPMG (1999) survey showed that almost three fourth of the number of companies provide their environmental information in their annual report and one fourth of the companies provide them in separate environmental reports. Whereas, Razeed et al. (2004) indicated that majority of US resource companies primarily used annual reports (both hard copy and interned-based) to disclose their environmental information, but failed to exploit the power of other media.

Results of a survey conducted by Guo (2005) revealed that environmental reporting of Chinese firms are characterized as ill-regulated when it comes to the content and format of their environmental reports - some companies provide the information in their annual reports, others on their websites and some others by other means such as environmental reports and newspapers and magazines. Particularly, Guo (2005) indicated that of 54 companies, 8 (14.8\%) companies disclosed environmental information in environmental reports, 16 (29.6\%) companies in environmental brochure, $36(66.7 \%)$ companies disclosed in corporate brochure, $15(27.8 \%)$ in financial statement, $25(46.3 \%)$ on website, $19(35.2 \%)$ in receive tours to factory, 5 (9.3\%) in meeting with residents, 11 (20.4\%) on television or radio, $14(25.9 \%)$ in newspaper or magazine, $10(18.5 \%)$ at seminars or symposium, and $3(5.6 \%)$ through other media. Thus, the study revealed no uniform format of environmental reporting among Chinese companies.

Chatterjee and Mir (2006) indicated that Indian firms offer greater environmental information on their websites than on their annual reports. Jenkins and Yakovlenva (2006) examined social disclosure among the leading 10 global mining firms and the study showed that in 2003 alone, out of the ten firms that produced annual reports, seven produced a stand-alone social and environmental report, and one produced a specific volume of social and environmental report and made it a part of the annual report. Moreover, all ten companies published information on their social and environmental issues on their websites in 2004.

With the aim of identifying the status and progress of environmental reporting, Mak, Chan, Wong and Zheng (2007) examined the environmental reports of a sample of airlines in Europe and the Asia Pacific region. The study revealed that only airlines in 12 countries have published stand-alone environmental reports. The study showed that European and Asian airlines have devoted varying degrees of effort and resources to producing stand-alone environmental reports, and the reports produced by European airlines were richer in content than those of their counterparts in Asia.

A few previous studies relating to social and environmental disclosure have combined more than one reporting medium, and a very few studies have compared the social and 
environmental disclosures made in various reporting mediums. For example, Zeghal and Ahmed (1990) compared between three mediums used by corporations to disclose social information, namely, annual report, brochures and advertisements (radio, television, and newspapers) in regards to their type and format of information disclosure. The study indicated that in terms of the number of words, brochures play the most important role in the social information disclosure. They are followed by the annual reports, whereas advertisements play a very minor role in the total social information disclosure. Zeghal and Ahmed (1990) suggested that social information provided by a firm in its annual reports may not be complete, and as such, other disclosure mediums, such as, brochures are often used by firms to supplement the annual reports.

Tilt (1994) investigated pressure groups' perceptions (sufficiency, ease of understanding and credibility) of corporate social disclosure in various media (annual report, supplements to the annual report or generated at interim dates, booklets or leaflets addressing the company's social activities, advertisements and product labels). The study indicated that there is strong agreement that the amount of corporate social responsibility disclosure is insufficient. The study also indicated that, the most commonly used medium for social responsibility disclosure are the annual reports. While, the most commonly received form of social disclosure are advertisements followed by annual reports. In terms of understandability, the study revealed that advertisements are considered as the easiest form of the social disclosure to understand, followed by supplements, while annual reports scored a median rank for understanding. In terms of credibility, the study revealed that annual reports scored a median, while advertisements and supplements were seen to be low in credibility.

Williams and Pei (1999) investigated corporate social disclosures in annual reports and corporate websites of companies from four countries (namely, Australia, Singapore, Malaysia, and Hong Kong). The results revealed that Australian and Singaporean companies disclosed more CSR information on their websites than in annual reports, while, for companies belong to Malaysia and Hong Kong there were no significant differences between the two mediums. However, the study showed that companies in all countries appeared to provide more narrative information on their websites than annual reports.

Buhr and Freedman (2001) examined three media for environmental disclosure namely, annual reports, security exchange filings (the $10 \mathrm{~K}$ in the US and the Annual Information Form in Canada) and environmental reports. The study found that various firms that generate environmental reports are shifting much of their voluntary environmental performance information from their annual reports to their environmental reports to prevent information duplication. The study also concluded that the disclosure of Canadian firms increased more dramatically than the disclosure of US firm's disclosure, which was initially greater, and concluded that Canadian culture and institutional infrastructure is more conducive to the 
Print ISSN: 2053-4086(Print),

Online ISSN: 2053-4094(Online)

production of environmental disclosure than US counterparts. Canadian firms produced a greater level of voluntary environmental disclosure, especially in the environmental report, while the US firms produced more of the mandated disclosure in the $10 \mathrm{~K}$ and annual report.

Branco and Rodrigues (2008) compared the level of corporate social responsibility disclosure in the annual reports and websites of Portuguese companies. They found that companies in Portugal disclosed more corporate social responsibility information in their annual reports than on websites, and they suggested that companies prefer the annual report as a corporate social responsibility disclosure medium. Yusoff and Lehman (2008) showed that companies disclosed more environmental information in stand-alone reports and corporate websites compared to disclosure made in annual report. Sawani, Zain and Darus (2010) examined the sustainability reporting and assurance practices in Malaysia. The study indicated that most of the information relating to sustainability disclosure reported is integrated in the annual report and with no assurance statement.

In Bangladesh, Islam and Islam (2011) examined the environmental disclosure in annual reports, press releases and stand-alone social responsibility reports of Niko company (a multinational oil and gas company operating in Bangladesh) over the period 2004-2007. They have found that the company annual reports and press releases adequately disclosed its environmental contingent liability, but they did not provide any information about the issue of the local community who were affected by the blowouts, instead the company utilized a stand-alone report to address this issue. De Villiers and Van Staden (2011) compared environmental disclosures on websites and in annual reports of 120 companies in North American. The study revealed that there the levels of environmental disclosures in annual reports and on corporate websites are different.

Similarly, Sobbani, Amran and Zainuddin (2012) investigated the sustainability disclosure of Bangladeshi banks in their annual reports and corporate websites. They revealed that disclosure is taking place more in annual reports than on web sites. Yusoff et al. (2013) indicated that most of items disclosed in stand-alone reports (environmental reports, social and sustainability reports), corporate websites, and corporate newsletters showed higher mean average when compared to disclosures made in annual report. Thus, the study concluded that other reports are more favourable than annual reports in disclosing environmental information.

On the contrary, some previous studies found no differences between different mediums. For example, Cormier and Magnan (2004) found no significant variation between different disclosure media of sample companies listed on the Toronto Stock Exchange, as they found an extensive overlap of print disclosure and website disclosure. Suttipun and Stanton (2012) found no different amount of environmental disclosures made in annual reports and on 
websites of Thai listed companies.

However, Buhr (1994) indicated mixed results, as the study showed that there is a difference between annual reports and environmental reports with regard to quantity, subject matters, type of information, and tense used. While the study found no difference in the quantity of environmental disclosure provided through annual reports and SOC filling mandated by Securities regulations, there were few differences found between the natures of the environmental disclosure provided through the two media. The results on possible differences in information type included in the two media were not conclusive. In addition, the study revealed that there are no differences between SOC filling and annual reports with regard to the use of subject matter. Thus, the study found differences between some media, but found no difference between other media. Buhr (1994) suggested that more research is needed to compare between different reporting media.

As mentioned before, the majority of previous studies relating to social and environmental disclosure have covered a single media of reporting (mostly annual reports), while, there is a lack of interest in studying quality of disclosure in other mediums such as stand-alone reports and corporate websites (Hassan, 2010; Suttipun and Stanton, 2012). A few studies have combined more than one reporting medium. For example, KPMG (1993,1996 and1999), Hassan (2010), Sawani et al. (2010), Eltaib (2012), and Yusoff and Darus (2014) considered disclosure in both annual report and stand-alone report.

Other studies, for example, Williams and Pei (1999), Branco and Rodrigues (2008), Suttipun and Stanton (2012), Sobbani et al. (2012) and Kamla and Rammal (2013) considered annual report and corporate websites, and Adams et al. (1998) considered annual reports and press release. Some other studies considered three reporting mediums, such as, annual reports, brochures and mass mediums advertisements (cf. Zeghal and Ahmed, 1990), annual reports, stand-alone reports and security exchange filings (cf. Buhr, 1994; Buhr and Freedman, 2001), annual reports, stand-alone reports and press releases (cf. Gamble et al., 1996; Islam and Islam, 2011; Patten, 1992), stand-alone reports, websites and corporate newsletters (cf. Yusoff et al., 2013), annual reports, stand-alone reports and websites (cf. Cuesta and Valor, 2013; Kaur, 2015). However, some studies considered more reporting mediums; for example, Tilt (1994) investigated corporate social disclosures in annual report, supplements, booklets, advertisements and product labels.

Most of the studies that covered mediums other than annual reports did not analyze the other mediums separately; instead they were analyzed as additional sources (Sapkauskiene and Leitoniene, 2014). Very few previous studies have compared the environmental disclosures made in various reporting mediums. In this regard, the previous studies concerned with different subjects, such as the medium used by companies (e.g. Jenkins and Yakovlenva, 2006; 
KPMG, 1999; Mak et al., 2007; Guo, 2005; Razeed, et al., 2004), how much is disclosed or extent/ quantity of disclosure (e.g. Branco and Rodrigues, 2008; Buhr and Freedman, 2001; Chatterjee and Mir, 2006; Cormier and Magnan, 2004; De Villiers and Van Staden, 2011; Islam and Islam, 2011; Sobbani et al., 2012; Suttipun and Stanton, 2012; Williams and Pei (1999; Yusoff and Lehman, 2008; Yusoff et al., 2013), what is disclosed (type) and format of information disclosed (e.g. Zeghal and Ahmed, 1990), or based on several dimensions, such as quantity, subject matters, type of information, and tense used (e.g. Buhr, 1994). However, these studies revealed mixed results. Some studies indicated differences between different mediums, while, some other studies found no differences. Moreover, no study has compared between different media based on their quality.

In sum, while a few previous studies compared between different disclosure media, they did not consider the quality of disclosure, and instead considered the extent, nature and other aspects of disclosure. However, these studies have revealed contradictory findings. Given the fact that, the companies use different media to disclose their environmental information and as users cannot identify and read all media, it is useful for them to determine the medium that contains environmental information with high level of quality. It was argued that examining other social and environmental reporting mediums such as stand-alone reports and corporate websites and comparing these alternative mediums to annual reports may reveal noteworthy insights on different practices of corporate communication on social and environmental information (Nurhayati, Taylor and Tower, 2015). All of the above arguments provide motivation for further investigation. Thus, quality of disclosure made in annual reports, stand-alone reports and corporate homepages were comparatively examined in this study. This will help various stakeholders of companies to choose a certain medium of disclosure that they can rely on to extract environmental information with high degree of quality to enable them to make decisions. This study is the first study that made this comparison in order to fill gap in the literature.

\section{RESEARCH METHODS}

In order to achieve the objective of this study, this study adopted a quantitative research methodology and probability cluster sampling technique was employed. A number of 116 oil and gas companies originated from 19 developing countries were included in the sample. To measure quality of environmental disclosure, a 42-items disclosure index was developed by adapting pertinent established indices. The study also used Wiseman`s (1982) scoring scheme which was widely adopted by many pertinent studies (e.g. Kuo and Chen, 2013; Sulaiman et al., 2014; Zeghal \& Ahmed, 1990). Using Wiseman's scoring method; the present study appropriates the greatest weight (3) to quantitative disclosures. This is followed by the next highest weight (2) that is appropriated to non-quantitative but distinct information related to indicators. The lowest weight (1) is granted to general qualitative disclosures, whereas, a zero 
is granted to firms who do not provide information regarding a specific indicator. Thus, the total possible maximum score for the overall environmental disclosure index is 126 (i.e. $3 \times 42=126$ ). The scores are converted into percentages by dividing the disclosure score of each company to the maximum possible score. The financial year ends at December 31, 2010, or the financial year ends at June 30, 2010, or the financial year ends at March 31, 2011, depending on an end of a company`s financial year, was chosen for the research. Annual reports, stand-alone reports and environmental related sections on homepages were downloaded from companies`websites. The collected data was analyzed using the Statistical Package for Social Sciences (SPSS) version 19.0 software. Various statistical techniques were applied: a) goodness of data was examined by testing validity and reliability of the data; b) in order to getting feel of the data and obtain an understanding of the data, descriptive statistics including minimum, maximum, mean and standard deviation were applied and then, c) the means of environmental disclosure quality in three disclosure mediums (AN, STAN and HOM) are compared using univariate analysis of variance (ANOVA).

\section{RESULTS AND DISCUSSIONS}

The study assessed the quality of environmental disclosure made by the companies in the three main reporting mediums. The disclosure index and scoring system were used. Thus, each reporting medium for each company in the sample was carefully read and every sentence was evaluated by determining which index item was covered in the sentence and then the appropriate scale was applied to score it for quality. Total scores were calculated for each index category and for the index as a whole. Based on the disclosure index (comprises 42 items) and scoring system (range from 0 to 3 scores) used in this study, theoretically, a company can score a maximum of 126 points $(42 \times 3)$.

Table 1 displays the descriptive statistics for the environmental disclosure quality of the 116 companies in the sample. It shows the means for each of the eight index categories and overall quality of environmental disclosure. The table shows that the range of environmental disclosure quality scores varies widely, from 33 to 106. It also shows that the mean score of total environmental disclosure quality per company is 68.98. Thus, the scores of 68.98 represent $54.75 \%$ out of all possible environmental disclosure scores of 126 (i.e., 42 items $\times$ maximum score of 3). This level of disclosure quality is similar to that found by Eljayash et al. (2012) who revealed that the average of quality of CED in annual reports by oil companies in the Arab oil countries was 26.66 (55.54\%) in 2010. However, the level of environmental disclosure quality of the current study is relatively high compared to those found by the majority of previous studies (cf. Ahmad and Haraf, 2013; Comyns and Figge, 2015; Cuesta and Valor, 2013; Dong, Fu, Gao and Ni, 2015; Haji, 2013; Harun, Abdul Rashid and Alrazi, 2013; Hooks \& Van Staden, 2011; Michelon, Pilonato and Ricceri, 2015; Sulaiman et al., 2014). 
Table 1: Descriptive Statistics of Environmental Disclosure Categories

\begin{tabular}{lllllll}
\hline Categories & Min. & Max. & Sum & Mean & $\begin{array}{l}\text { Average } \\
\text { Mean }\end{array}$ & $\begin{array}{l}\text { Std. } \\
\text { Deviation }\end{array}$ \\
\hline Economic factors & 0 & 15 & 814 & 7.02 & 1.404 & 4.230 \\
$\begin{array}{l}\text { Laws and regulations } \\
\text { Pollution abatement }\end{array}$ & 0 & 9 & 338 & 2.91 & .97 & 1.722 \\
$\begin{array}{l}\text { Sustainable development } \\
\text { Disturbances to land and }\end{array}$ & 0 & 17 & 1390 & 11.98 & 2 & 2.804 \\
$\begin{array}{l}\text { land remediation } \\
\begin{array}{l}\text { Spills \& environmental } \\
\text { incidents }\end{array}\end{array}$ & 0 & 9 & 985 & 8.49 & 2.123 & 2.472 \\
$\begin{array}{l}\text { Environmental } \\
\text { management }\end{array}$ & 2 & 26 & 1890 & 16.29 & 1.629 & 4.936 \\
Health and safety & 6 & 21 & 1726 & 14.88 & 1.86 & 3.182 \\
\hline Total & $\mathbf{3 3}$ & $\mathbf{1 0 6}$ & $\mathbf{7 9 9 7}$ & $\mathbf{6 8 . 9 8}$ & & $\mathbf{1 5 . 5 1 4}$ \\
\hline $\mathrm{N}=116$ & & & & & & \\
\end{tabular}

Table 1 also presents the level of quality of environmental disclosure for each of eight categories. It shows that the quality of environmental disclosure of each category is different. The results revealed that the quality of environmental disclosure varies by disclosure category. It can be seen that "Environmental management" achieved the highest disclosure mean score of 16.29 , followed by "Health and safety" category with a mean score of 14.88 , whereas the category of "Spills \& environmental incidents" has the lowest mean score (2.40). Based on average mean, the category of "sustainable development" has the highest average mean of scores of 2.123, followed by "pollution abatement" (average mean of 2), "health and safety" (1.86), "disturbances to land and land remediation" (1.657), "environmental management" (1.629), "economic factors" (1.404), "laws and regulations" (0.97), and lastly, the "spills \& environmental incidents" category has the lowest average mean ( 0.80$)$.

The study also assessed the quality of environmental disclosure of each reporting medium by determining the average scores for each. This analysis gives a clear understanding of the disclosure media that oil and gas companies in developing countries prefer to use as vehicle for their environmental disclosure. Table 2 displays the descriptive statistics of the environmental disclosure quality. It indicates that the level of quality of environmental disclosure in the three media has a wide range. While the minimum disclosure obtained is 13 scores for the annual reports and the same for the homepages, the maximum is 106 scores for the stand-alone. Also, for each investigated medium a wide range of environmental disclosure quality can be noted. Thus, the quality of environmental disclosure in annual reports ranges from 13 to 96 scores, in stand-alone reports ranges from 20 to 106, while it ranges from 13 to 
Online ISSN: 2053-4094(Online)

75 scores in homepages. It can be seen that stand-alone reports have the highest mean of scores of environmental disclosure with 65.64 scores followed by annual reports with 52.63 scores, and finally, homepages with 38.53 scores. Thus, there is a variation in the quality of environmental disclosure among the three mediums, with the highest scores in stand-alone reports.

Table 2: Descriptive Statistics of Quality of Environmental Disclosure in Different Media

\begin{tabular}{llllll}
\hline Reporting Mediums & N & Min. & Max. & Mean & $\begin{array}{l}\text { Std. } \\
\text { Deviation }\end{array}$ \\
\hline Annual Reports & 116 & 13.00 & 96.00 & 52.6293 & 15.40386 \\
Stand-alone Reports & 116 & 20.00 & 106.00 & 65.6379 & 17.03520 \\
Homepages & 116 & 13.00 & 75.00 & 38.5345 & 14.29286 \\
\hline
\end{tabular}

Moreover, a one-way analysis of variance (ANOVA) has been conducted to test whether there are any significant differences among the means of the environmental disclosure scores for the various reporting mediums (namely, annual reports, stand-alone reports and corporate homepages $)$. The F-ratio, equal to 87.384 , and a p-value $=0.000(<0.05)$ indicate that there is a statistically significant difference between the mean environmental disclosure score from one mediums to another at the $95.0 \%$ confidence level (see Table 3). Therefore, it is concluded that there is a statistically significant difference among the three mediums of environmental disclosure.

Table 3: Summary of ANOVA

Total Scores

\begin{tabular}{l|lllll}
\hline \multirow{2}{*}{ Between Groups } & Sum of Squares & Df & Mean Square & F & Sig. \\
\cline { 2 - 6 } Within Groups & 42629.431 & 2 & 21314.716 & 87.384 & 0.000 \\
Total & 84152.716 & 345 & 243.921 & & \\
\hline
\end{tabular}

Descriptive statistics (see Table 2 above) and One-way ANOVA results (see Table 3 above) showed that the disclosure mediums were statistically different for the environmental disclosure quality. Means ranged from 38.53 to $65.64(\mathrm{p}=0.000)$ indicating that environmental disclosures do differ from medium to medium. As P-values of 0.00 is less than the criterion value of 0.05., the null hypothesis can be rejected, and it can be concluded that there is a statistically significant difference among the means for the disclosure index for the three disclosure mediums and that there is a statistically significant difference among the three mediums of environmental disclosure. 
Because the test was significant, Post hoc LSD multiple comparisons were conducted to determine where differences between means existed. The analysis (see Table 4) revealed that the mean of environmental disclosure in stand-alone reports was statistically significantly higher than in other mediums.

Table 4: LSD Multiple Comparison

Total Scores

\begin{tabular}{|c|c|c|c|c|c|c|}
\hline \multirow{2}{*}{$\begin{array}{l}\text { (I) } \\
\text { Disclosure } \\
\text { Medium }\end{array}$} & \multirow[b]{2}{*}{$\begin{array}{l}(\mathrm{J}) \text { Disclosure } \\
\text { Medium }\end{array}$} & \multirow{2}{*}{$\begin{array}{l}\text { Mean } \\
\text { Difference } \\
(\mathrm{I}-\mathrm{J})\end{array}$} & \multirow[b]{2}{*}{ Std. Error } & \multirow[b]{2}{*}{ Sig. } & \multicolumn{2}{|c|}{$95 \%$ Confidence Interval } \\
\hline & & & & & Lower Bound & Upper Bound \\
\hline \multirow[t]{2}{*}{$\mathrm{AN}$} & STAN & $-13.00862-*$ & 2.05074 & 0.000 & $-17.0421-$ & $-8.9751-$ \\
\hline & HOM & $14.09483 *$ & 2.05074 & 0.000 & 10.0613 & 18.1284 \\
\hline \multirow[t]{2}{*}{ STAN } & AN & $13.00862^{*}$ & 2.05074 & 0.000 & 8.9751 & 17.0421 \\
\hline & $\mathrm{HOM}$ & $27.10345^{*}$ & 2.05074 & 0.000 & 23.0699 & 31.1370 \\
\hline \multirow[t]{2}{*}{ HOM } & AN & $-14.09483-*$ & 2.05074 & 0.000 & $-18.1284-$ & $-10.0613-$ \\
\hline & STAN & $-27.10345-*$ & 2.05074 & 0.000 & $-31.1370-$ & $-23.0699-$ \\
\hline
\end{tabular}

*The mean difference is significant at the 0.05 level.

The results of the descriptive statistics indicated great variations in the quality of environmental disclosure among different reporting mediums. It is shown that the quality of environmental disclosure in annual reports ranges from 13 to 96 scores with a mean of 52.63, in stand-alone reports ranges from 20 to 106 with a mean of 65.64, while it ranges from 13 to 75 scores with a mean of 38.53 in homepages.

The results of ANOVA test confirmed the variation in the quality of environmental disclosure among the three mediums is significant $(\mathrm{F}(2,345)=87.384, \mathrm{p}=0.000)$. It can be seen that stand-alone reports have the highest mean of scores of environmental disclosure quality (65.64) followed by annual reports (52.63), while, the homepages have the lowest mean (38.53). Thus, the environmental disclosure quality in stand-alone environmental reports is statistically significantly higher than in other mediums, followed by annual reports, and lastly, corporate homepages had the lowest level of the environmental disclosure quality. These results indicate that, most of oil and gas companies in developing countries prefer stand-alone reports as medium of environmental disclosure followed by annual reports..The result also signifies that the full potential of the website to report and communicate environmental information is not effectively utilized.

Primarily, this finding is in line with some previous studies. For example, Zeghal and Ahmed (1990) indicated that in terms of the number of words, different disclosure media play 
European Journal of Accounting, Auditing and Finance Research

Vol.8, No.4, pp.121-148, April 2020

Published by ECRTD-UK

Print ISSN: 2053-4086(Print),

Online ISSN: 2053-4094(Online)

different roles in the total social information disclosure, and Buhr (1994) who found difference between annual reports and environmental reports with regard to quantity, subject matters, type of information, and tense used. This finding also is consistent with Kuo and Chen (2013) who pointed that companies are more active in using stand-alone reports as an effective tool to establish their legitimacy image.

This finding also supports findings of some prior studies. For example, Buhr and Freedman (2001) who indicated that various companies generating environmental reports are moving much of their environmental disclosures out of the annual report and into the environmental report. Branco and Rodrigues (2008) found that environmental information is more disclosed in annual reports than on the internet. Vuorela (2014) pointed that on cases where companies have increasingly produced separate environmental reports, it can be possible to find very little environmental performance information in the annual report. The finding is also consistent with findings from some previous studies which reveal that disclosure is taking place more in annual reports than on web sites (cf. Sobbani et al., 2012). However, the relatively low level of disclosure quality on homepages consistent with Joseph et al. (2014) and Lodhia et al. (2012) in that the full potential of the website to report and communicate environmental and sustainability information is not effectively utilized.

On the contrary, this result is inconsistent with the result obtained by Tilt (2001b) who indicated that the annual report is still considered an appropriate medium for environmental disclosure, Cormier and Magnan (2004) who found no statistically significant difference between the different environmental disclosure mediums, Chatterjee and Mir (2006) who indicated that companies provide more environmental information on their websites than the information provided in their annual reports. The finding of this study is also inconsistent with that of Ramdhony et al. (2010), which revealed that the annual report is the most common medium used to disclose environmental information followed by stand-alone report and internet web pages, and Suttipun and Stanton (2012) who did not find different amount of environmental disclosures made in annual reports and on websites.

A possible explanation for this finding may be due to the fact that stand-alone environmental reports are very carefully designed, glossy and voluminous documents (Gray and Bebbington, 2001). Buhr and Freedman (2001) contended that, where firms generated stand-alone environmental reports, it is possible to find minimal information concerning environmental performance within their annual reports. Hassan (2010) argued that the presence of stand-alone reports could affect social disclosure in annual reports. He argued that "it is possible that companies that produce corporate responsibility reports could decrease the quantity of social and environmental information in their annual reports based on the presence of this information in their stand-alone reports" (p. 81). 
Moreover, this result can be interpreted by the argument that, "while audited information is viewed more credibly, non-audited sections are likely to contain more environmental information. In the absence of mandatory requirements, and because disclosure in audited sections requires additional cost of ensuring compliance with the laws and regulations, companies would rather that their environmental disclosure be non-audited and they are willing to provide more environmental disclosures in those sections" (Mitchell, et al., 2006).

\section{CONCLUSIONS AND POLICY IMPLICATIONS}

The objective of this study is to investigate whether there is any significant difference between different reporting mediums (namely, annual report, stand-alone reports, and corporate homepages) regarding their environmental disclosure quality of oil and gas companies in developing countries. The results confirmed the variation in the quality of environmental disclosure among the three mediums is significant. Thus, the environmental disclosure quality in stand-alone environmental reports is statistically significantly higher than in other mediums, followed by annual reports, and lastly, corporate homepages had the lowest level of the environmental disclosure quality. This could suggest that majority of oil and gas companies in developing countries prefer stand-alone reports as media of environmental disclosure. These results reflect the importance of the stand-alone reports to information users. The results also signify that the full potential of the website to report and communicate environmental information is not effectively utilized.

The current study contributes to prior literature on environmental disclosure by focusing on the variance in the content-quality of environmental disclosure among different reporting mediums (namely, annual reports, stand-alone reports and corporate homepages). This enables interested parties understanding of how companies use different reporting media to disclose their environmental information. Specifically, for information users, it is important to know which medium/s is/are better to be relied on to help in decision making of information users. Thus, the findings of this study will facilitate an in-depth understanding of the selection of disclosure medium of environmental information. However, taking into account that reviewing all reporting mediums used by a company for its environmental information is difficult and time consuming for readers, these results imply that information users, specifically those concerned with environmental aspects can rely on stand-alone reports and annual reports, as they provide better quality disclosure. It is also hoped that the findings of this study serve as input towards the development of improved regulations concerning environmental reporting for the oil and gas industry, and provide guidelines to the regulators to make relevant decisions on environmental information items to be incorporated in the regulatory standards. 
European Journal of Accounting, Auditing and Finance Research

Vol.8, No.4, pp.121-148, April 2020

Published by ECRTD-UK

Print ISSN: 2053-4086(Print),

Online ISSN: 2053-4094(Online)

\section{References}

1. Abdalla, Y. A. and Siti-Nabiha, A. K. (2015). Pressures for Sustainability Practices in an Oil and Gas Company: Evidence from Sudan. Qualitative Research in Accounting \& Management, 12) 3), 256-286.

2. Adams, C. A. (2002). Internal Organizational Factors Influencing Corporate Social and Ethical Reporting - beyond Current Theorizing. Accounting, Auditing \& Accountability Journal, 15 (2), 223-250.

3. Adams, C. A., \& Frost, G. R. (2004). The Development of the Corporate Website and Implications for Ethical, Social and Environmental Reporting through these Media, The Institute of Chartered Accountants of Scotland, Edinburgh.

4. Adams, C. A., Hill, W. Y., \& Roberts, C. B. (1998) Corporate Social Reporting Practices in Western Europe: Legitimating Corporate Behaviour. The British Accounting Review, 30(1), $1-21$.

5. Ahmad, N. N. and Haraf, A. S. (2013). Environmental Disclosures of Malaysian Property Development Companies: Towards Legitimacy or Accountability? Social Responsibility Journal, 9(2), 241-258.

6. Al-Arussi, A. S., Selamat, M. H. and Hanefah, M. M. (2009). Determinants of Financial and Environmental Disclosures through the Internet by Malaysian Companies. Asian Review of Accounting, 17 (1), 59-76.

7. Alrazi, B., De Villiers, C. and Van Staden, C. (2016). The Environmental Disclosures of the Electricity Generation Industry: A Global Perspective. Accounting and Business Research, 46(6), 665-701.

8. Alias, N. A. (2001). An Investigation of Environmental Disclosure By Local Listed Companies And Multinational Companies (MNCs) In Malaysia For The Period Ended 1999: An Empirical Evidence. Unpublished Master Thesis, University Teknologi Mara (UiTM).

9. Bani-Khalid, T., Kouhy, R . and Hassan, A. (2017).The Impact of Corporate Characteristics on Social and Environmental Disclosure (CSED): The Case of Jordan. Journal of Accounting and Auditing: Research \& Practice, 1-28.

10. Barr, M. A. (2007). Corporate Social Responsibility Reporting in Emerging Economies: A Case of the Petroleum Refining Industry. Unpublished Master Thesis. Duke University.

11. Branco, M. C., \& Rodrigues, L. L. (2008). Factors Influencing Social Responsibility Disclosure by Portuguese Companies. Journal of Business Ethics, 83, 685-701.

12. Brink, P., Haines, R., Owen, S., Smith, D., \& Whitaker, B. (1997). Consulting the Stakeholder: A New Approach to Environmental Reporting for IBM (UK) Ltd. In G Ledgerwood (Ed.), Greening the Boardroom: Corporate Governance and Business Sustainability (175-187). Sheffield, UK: Greenfield Publishing.

13. Buhr, N. (1994). Environmental Disclosure: An Empirical Study of Corporate Communication in Canada and the Role of Accounting. Unpublished $\mathrm{PhD}$ Thesis, The University of Western Ontario, London, Ontario. 
European Journal of Accounting, Auditing and Finance Research

Vol.8, No.4, pp.121-148, April 2020

Published by ECRTD-UK

Print ISSN: 2053-4086(Print),

Online ISSN: 2053-4094(Online)

14. Buhr, N., \& Freedman, M. (2001). Culture, institutional factors and differences in environmental disclosure between Canada and the United States. Critical Perspectives on Accounting, 12(3), 293-322.

15. Campbell, D. (2003). Intra- and Intersectoral Effects in Environmental Disclosures Evidence for Legitimacy Theory?. Business Strategy and the Environment, 12(6), 357-371.

16. Chatterjee, B., \& Mir, M. Z. (2006). The Rhetoric of Environmental Reporting: The Case of India. Presented at the Accounting and Finance Association of Australia and New Zealand (AFAANZ) Conference, Wellington, New Zealand, 2-4 July.

17. Coakes, S. J., Steed, L., \& Ong, C. (2010). SPSS: Analysis without Anguish: Version 17 for Windows, John Wiley and Sons, Australia.

18. Comyns, B. and Figge, F. (2015). Greenhouse Gas Reporting Quality in the Oil and Gas Industry: A Longitudinal Study Using the Typology of Search, Experience and Credence Information. Accounting, Auditing \& Accountability Journal, 28 (3), 403-433.

19. Cormier, D. and Gomez-Gutierrez, L. (2018). On the Search for Mimetic Patterns in Environmental Disclosure: An International Perspective. International Journal of Sustainable Development \& World Ecology, In Press, 24 February 2018, 1-17.

20. Cormier, D., \& Magnan, M. (2004). The Impact of the Web on Information and Communication Modes: The Case of Corporate Environmental Disclosure. International Journal of Technology Management, 27(4), 393-416.

21. Cormier, D., Ledoux, M., \& Magnan, M. (2009). Social and Environmental Disclosure: Substitutes or Complements?. Working Paper Chaire d'information financiere et organisationnelle, Cahier de Recherche, February 2009.

22. Cuesta, M. and Valor, C. (2013). Evaluation of the Environmental, Social and Governance Information Disclosed by Spanish Listed Companies. Social Responsibility Journal, 9 (2), $220-240$.

23. De Villiers, C., \& Van Staden, C. (2011). Where Firms Choose to Disclose Voluntary Environmental Information. Journal of Accounting and Public Policy, 30 (6), 504-525.

24. Deegan, C. and Rankin, M. (1997). The Environmental Reporting Expectations Gap: Australian Evidence, A Paper Presented in the Inaugural Conference of the Asia-Pacific Network Schools of Accounting, Curtin University, Perth, Australia, April 4-5, 1997.

25. Deegan, C., Rankin, M., \& Tobin, J. (2002). An Examination of the Corporate Social and Environmental Disclosures of BHP from 1983-1997: A Test of Legitimacy Theory. Accounting, Auditing \& Accountability Journal, 15(3), 312-43.

26. Dibia, N. O. and Onwuchekwa, J. C. (2015). Determinants of Environmental Disclosures in Nigeria: A Case Study of Oil and Gas Companies. International Journal of Finance and Accounting, 4(3), 145-152.

27. Dong, Y., Fu, R., Gao, F. and Ni, C. (2015). Determinants and Economic Consequences of Nonfinancial Disclosure Quality. Retrieved June 3, 2015, from http://papers.ssrn.1com/sol3/papers.cfm?abstract_id=2555416

28. Eljayash, K., James, K. and Kong, E. (2012). The Quantity and Quality of Environmental 
European Journal of Accounting, Auditing and Finance Research

Vol.8, No.4, pp.121-148, April 2020

Published by ECRTD-UK

Print ISSN: 2053-4086(Print),

Online ISSN: 2053-4094(Online)

Disclosure in Annual Reports of National Oil and Gas companies in Middle East and North Africa. International Journal of Economics and Finance, 4 (10), 201-217.

29. Eljayash, K., Kavanagh, M. and Kong, E. (2013). Environmental Disclosure Practices in National Oil and Gas companies and International Oil and Gas Corporations Operating in Organization of Arab Petroleum Exporting Counties. International Journal of Business, Economics and Law, 2 (1), 35-52.

30. Eltaib, E. E. (2012). Environmental Accounting Disclosures of Australian Oil and Gas Companies. Unpublished Master Thesis, University of Wollongong.

31. Frynas, J. G. (2009). Beyond Corporate Social Responsibility: Oil Multinationals and Social Challenges. Cambridge University Press. Retrieved July 29, 2009, from www.cambridge.org.

32. Gamble, G., Hsu, K., Jackson, C., \& Tollerson, C. (1996). Environmental Disclosures in Annual Reports: An International Perspective. The International Journal of Accounting, 31(3), 293-331.

33. Gray, R., \& Bebbington, J. (2001). Accounting for the Environment, ( $2^{\text {nd }}$ ed.). London: Sage.

34. Gray, R., Javad, M., Power, D., \& Sinclair, C.D. (2001). Social and Environmental Disclosure and Corporate Characteristics: A Research Note and Extension. Journal of Business Finance \& Accounting, 28(3) \& (4), 327-356.

35. Guo, P. (2005). Corporate environmental reporting and disclosure in China, (Unpublished doctoral dissertation), Tsinghua University, Beijing.

36. Hair, J., Money, A., Page, M., \& Samouel P. (2007). Research Methods for Business. John Wiley \& Sons Ltd. US.

37. Haji, A. A. (2013). Corporate Social Responsibility Disclosures over Time: Evidence from Malaysia. Managerial Auditing Journal, 28 (7), 647-676.

38. Harun, N. A., Abdul Rashid, A. and Alrazi, B. (2013). Measuring the Quality of Sustainability Disclosure among the Malaysian Commercial Banks. World Applied Sciences Journal, 28, 195-201.

39. Hassan, N. T. (2010). Corporate Social Responsibility Disclosure: An Examination of Framework of Determinants and Consequences. Unpublished PhD Thesis, Durham University, UK.

40. Hasseldine, J., Salama, A. I., \& Toms J. S. (2005). Quantity versus Quality: The Impact of Environmental Disclosures on the Reputations of UK Plcs. The British Accounting Review, 37, 231-248.

41. Heflin, F. and Wallace, D. (2014). The BP Oil Spill: Shareholder Wealth Effects and Environmental Disclosures. Retrieved May 17, 2015, from http://ssrn.com/abstract=1933531. 42. Hooks, J., \& Van Staden, C.J. (2011). Evaluating Environmental Disclosures: The Relationship between Quality and Extent Measures. The British Accounting Review, 43(3), 200-213.

43. Hossain, M. A., Islam, K. S., \& Andrew, J. (2006). Corporate Social and Environmental 
European Journal of Accounting, Auditing and Finance Research

Vol.8, No.4, pp.121-148, April 2020

Published by $\boldsymbol{E C R T D}-\boldsymbol{U K}$

Print ISSN: 2053-4086(Print),

Online ISSN: 2053-4094(Online)

Disclosure in Developing Countries: Evidence from Bangladesh. Paper presented at the Asian Pacific Conference on International Accounting Issues, Hawaii. Retrieved December 10, 2009, from http://ro.uow.edu.au/commpapers/179/.

44. IEA (2015). CO2 Emissions from Fuel Combustion (2015 edition). Retrieved November 29, 2015, from http://www.iea.org/publications.

45. Ioannou, I. and Serafeim, G. (2017). The Consequences of Mandatory Corporate Sustainability Reporting. Harvard Business School Working Paper, No. 11-100

46. Islam, M. A. and Islam, M. A. (2011). Environmental Incidents in A Developing Country and Corporate Environmental Disclosures. Society and Business Review, 6(3), 229-248.

47. Islam, S., Hosen A., \& Islam, M. (2005). An Examination of Corporate Environmental Disclosure by The Bangladesh Public Limited Companies. Pakistan Journal of Social Sciences, 3(9),1095-1102.

48. Ismail, A. H. (2017). Environmental Reporting: There Are Multiple Ways to Disclose Environmental Information. Oil \& Gas Financial Journal, 14 (9), 43-45.

49. Jenkins, H., \& Yakovleva N.(2006). Corporate Social Responsibility in the Mining Industry: Exploring Trends in Social and Environmental Disclosure. Journal of Cleaner Production, 14, 271-284.

50. Jones, K., Alabaster T., \& Walton J. (1998). Virtual Environments for Environmental Reporting. Greener Management International, 21, 121-137.

51. Jones, K., Alabaster, T., \& Hetherington, K. (1999). Internet-based Environmental Reporting: Current Trends. Greener Management International, 26, 69-90.

52. Jose, A., \& Lee, S. (2007). Environmental Reporting of Global Corporations: A Content Analysis based on Website Disclosures. Journal of Business Ethics, 72, 307-321.

53. Joseph, C., Pilcher, R. and Taplin, R. (2014). Malaysian Local Government Internet Sustainability Reporting. Pacific Accounting Review, 26 (1/2), 75-93.

54. Kamla, R. and Rammal, H. G. (2013). Social Reporting by Islamic Banks: Does Social Justice Matter?. Accounting, Auditing \& Accountability Journal, 26 (6), 911-945.

55. Kaur, M. (2015). Checking the Item wise Variation in the Environmental Reporting Practices of Indian Companies. The Macrotheme Review- A multidisciplinary journal of global macro trends, 4(1), 10-30.

56. Kotler, P., \& Lee, N.(2005). Corporate Social Responsibility: Doing the Most Good for Your Company and Your Cause. Wiley: Hoboken, NJ.

57. KPMG (1996). International Survey of Environmental Reporting 1996. Stockholm: KPMG.

58. KPMG (1999). KPMG International Survey of Environmental Reporting 1999 (KPMG Environmental Consulting, DeMeern, The Netherlands).

59. KPMG (2002). KPMG International Survey of Environmental Reporting 2002 (KPMG Environmental Consulting, DeMeern, The Netherlands).

60. KPMG (2008). KPMG International Survey of Corporate Responsibility Reporting 2008. Retrieved April 22, 2009, from http://www.kpmg.com 
European Journal of Accounting, Auditing and Finance Research

Vol.8, No.4, pp.121-148, April 2020

Published by ECRTD-UK

Print ISSN: 2053-4086(Print),

Online ISSN: 2053-4094(Online)

61. KPMG Global Sustainability Services. (2005). KPMG International Survey of Corporate Responsibility Reporting 2005. Retrieved April 22, 2009, from http://www.kpmg.com

62. KPMG Peat Marwick (1993). International Survey of Environmental Reporting. London: KPMG.

63. Kuo, L. and Chen, V. Y. (2013). Is Environmental Disclosure An Effective Strategy on Establishment of Environmental Legitimacy for Organization?. Management Decision, 51(7), 1462-1487.

64. Lodhia, S. K. (2005). Legitimacy Motives for World Wide Web (WWW) Environmental Reporting: An Exploratory Study into Present Practices in the Australian Minerals Industry. Journal of Accounting and Finance, 4, 1-15.

65. Lodhia, S. K. (2006). Corporate Perceptions of Web-based Environmental Communication- An Exploratory Study into Companies in the Australian Minerals Industry. Journal of Accounting and Organizational Change, 2 (1), 74-88.

66. Lodhia, S. K., Jacobs, K. and Park, Y. J. (2012). Driving public Sector Environmental Reporting: the Disclosure Practices of Australian Commonwealth Departments. Public Management Review, 14 (5), 631-647.

67. Mahmood, Z., Ahmad, Z., Ali, W. and Ejaz, A. (2017). Does Environmental Disclosure Relate to Environmental Performance? Reconciling Legitimacy Theory and Voluntary Disclosure Theory. Pakistan Journal of Commerce and Social Sciences, 11 (3), 1134-1152.

68. Mak, B. L., Chan, W. H., Wong, K., \& Zheng, C. (2007). Comparative Studies of Standalone Environmental Reports, European and Asian Airlines. Transportation Research Part D 12 (2007) 45-52.

69. Manasseh, S. (2004). Study on the Level of Corporate Social Disclosure Practices in Malaysia. Unpublished Master Thesis, Universiti Sains Malaysia.

70. Michelon, G., Pilonato, S. and Ricceri, F. (2015). CSR Reporting Practices and the Quality of Disclosure: An Empirical Analysis. Critical Perspectives on Accounting, 33, 59-78.

71. Mitchell, J., Percy, M., \& McKinlay, B. (2006). Voluntary Environmental Reporting Practices: A Further Study of 'Poor' Environmental Performers. Australian Journal of Corporate Law, 19(2), 182-215.

72. Mughal, S. L. (2014). Corporate Social Disclosure: A Case Study on Petroleum Industry of Pakistan. Journal of Economics and Sustainable Development, 5(11), 48-56.

73. Nurhayati, R., Taylor, G. and Tower, G. (2015). Investigating Social and Environmental Disclosure Practices by Listed Indian Textile Firms. Proceedings of the Australasian Conference on Business and Social Sciences 2015, Sydney (in partnership with The Journal of Developing Areas), p 201-212, ISBN 978-0-9925622-1-2.

74. Oba, V. C. and Fodio, M. I. (2012a). Comparative Analysis of Environmental Disclosures in Oil and Gas and Construction Industries in Nigeria. Journal of Sustainable Development in Africa, 14(6), 19-28.

75. Oba, V. C. and Fodio, M. I. (2012b). Board Characteristics and the Quality of 
European Journal of Accounting, Auditing and Finance Research

Vol.8, No.4, pp.121-148, April 2020

Published by ECRTD-UK

Print ISSN: 2053-4086(Print),

Online ISSN: 2053-4094(Online)

Environmental Reporting in Nigeria. Journal of Accounting and Management, 1(2), 33-48.

76. Okafor, T. G. (2018). Environmental Costs Accounting and Reporting on Firm Financial Performance: A Survey of Quoted Nigerian Oil Companies. International Journal of Finance and Accounting, 7(1), 1-6.

77. Patten, D. M. (1992). Intra-Industry Environmental Disclosure in Response to the Alaskan Oil Spill: A Note on Legitimacy Theory". Accounting, Organizations and Society, 17 (5), 471-475.

78. Prasad, M., Mishra, T. and Kalro, A. D. (2016). Environmental Disclosure by Indian Companies: An Empirical Study. Environment, Development and Sustainability, 19 (5), 1999-2022.

79. Ramdhony, D. Padachi, K., \& Giroffle, L. (2010). Environmental Reporting in Mauritian Listed Companies. International Research Symposium in Service Management. Le Meridien Hotel, Mauritius, 24-27 August 2010.

80. Rattanaphaphtham, K. and Kunsrison, R. (2011). Environmental Information Disclosure Quality, Competitive Advantage and Sustainable Growth of Thai Listed Firm: Perspective of Resource Based View. Journal of International Business and Economics, 11(3), 134-146.

81. Razeed, A., Tower, G., Hancock, P., \& Taplin, R. (2004). US Resource Company Environmental Disclosure Practices: What, Where and How? Presented at the Fourth Asia Pacific Interdisciplinary Research in Accounting Conference 4 to 6 July 2004 Singapore.

82. Roberts, R. W. (1992). Determinants of Corporate Social Responsibility Disclosure: An Application of Stakeholder Theory. Accounting Organizations and Society, 17(6), 595-612.

83. Sahore, N. S. and Verma, A. (2017). Environmental Disclosures and Size of Selected Indian Firms. European Scientific Journal, 13, 515-529.

84. Sapkauskiene, A. and Leitoniene, S. (2014). Corporate Social Responsibility Research Methods Analysis. European Scientific Journal, 1, 1857-7881.

85. Sawani, Y., Zain, M. M. and Darus, F. (2010). Preliminary Insights on Sustainability Reporting and Assurance Practices in Malaysia. Social Responsibility Journal, 6 (4), 627-645.

86. Sekaran, U. (2003). Research Methods for Business: A Skill Building Approach, (4th ed.). John Wiley \& Sons (Asia) Pte. Ltd., Singapore for manufacture and export.

87. Silva, T-A. D. (2008). Voluntary Environmental Reporting: The Why, What and How. Unpublished $\mathrm{PhD}$ thesis, Lincoln University.

88. Skillius, A., \& Wennberg, U. (1998). Continuity, Credibility and Comparability- Key Challenges for Corporate Environmental Performance Measurement and Communication. Lund: The International Institute for Industrial Environmental Economics at Lund University.

89. Sobbani, F. A., Amran, A. and Zainuddin, Y. (2012). Sustainability Disclosure in Annual Reports and Websites: A Study of the Banking Industry in Bangladesh. Journal of Cleaner Production, 23(1), 75-85.

90. Sulaiman, M., Abdullahb, N. and Fatima, A. H. (2014). Determinants of Environmental 
European Journal of Accounting, Auditing and Finance Research

Vol.8, No.4, pp.121-148, April 2020

Published by ECRTD-UK

Print ISSN: 2053-4086(Print),

Online ISSN: 2053-4094(Online)

Reporting Quality in Malaysia. International Journal of Economics, Management and Accounting, 22 (1), 63-90.

91. Susanto, A. and Mulyono, N. B. (2017). The Transitional Change on the Implementation of ISO 14001:2015 in Copper Ore Mill - Case Study. Journal of Ecological Engineering, 18(5),37-49.

92. Sustainability Ltd. \& UNEP (1999), The Oil Sector Report: A Review of Environmental Disclosure in the Oil Industry. Retrieved August 1,2009, from http://www.sustainabilty.com/downloadspublic/insight/reports/oilsector.pdf

93. Suttipun, M. and Stanton, P. (2012). The Differences in Corporate Environmental Disclosures on Websites and in Annual Reports: A Case Study of Companies Listed in Thailand. International Journal of Business and Management, 7 (14), 18-31.

94. Teoh, H. Y. \& Thong, G. (1984). Another Look at Corporate Social Responsibility and Reporting: An Empirical Study in a Developing Country. Accounting, Organizations \& Society, 9(2), 189-206.

95. Tilt, C. A. (1994). The Influence of External Pressure Groups on Corporate Social Disclosure: Some Empirical Evidence. Accounting, Auditing \& Accountability Journal, 7(4), 47-72.

96. Tilt, C. A. (2001a). Environmental Disclosure By Australian Companies: What Is Happening Outside the Annual Report? A paper Presented at the Asia Pacific Interdisciplinary Research in Accounting (APIRA) Conference, Adelaid, South Australia.

97. Tilt, C. A. (2001b). The Content and Disclosure of Australian Corporate Environmental Policies. Accounting, Auditing \& Accountability Journal, 14 (2), 190-212.

98. Unerman, J. (2000). Methodological Issues: Reflections on Quantification in Corporate Social Reporting Content Analysis. Accounting, Auditing \& Accountability Journal, 13(5), 667-681.

99. Vuorela, S. (2014). Environmental Disclosure in Finnish and Swedish Annual and sustainability Reports a Study of Forest Industry. Unpublished Bachelor Thesis in Accounting, University of Gothenburg.

100. Walden, W. D., \& Schwartz, B. N. (1997). Environmental Disclosures and Public Policy Pressures. Journal of Accounting Public Policy, 16(2), 125-154.

101. Wei, J. and Wang, I. (2016). Environmental Disclosure, Investors' Investment Decisions and their Perceptions of the Credibility of Management. Global Journal of Business Research, 10(4), 17-25.

102. Welbeck, E. E., Owusu, G. M., Bekoe, R. A. and Kusi, J. A. (2017). Determinants of environmental disclosures of listed firms in Ghana. International Journal of Corporate Social Responsibility, 1, 2-11.

103. Wheeler, D., \& Elkington, J. (2001). The End of the Corporate Environmental Report? Or the Advent of Cybernetic Sustainability Reporting and Communication. Business Strategy and the Environment, 10(1), 1-10.

104. Williams, S. M., \& Pei, C. A. H. W. (1999). Corporate Social Disclosures by Listed 
Companies on their Web Sites: An International Comparison. The International Journal of Accounting, 34(3), 389-419.

105. Wiseman, J. (1982). An Evaluation of Environmental Disclosure Made in Corporate Annual Reports. Accounting, Organizations and society. 7(1), 53-63.

106. Wong, H. and Wong, R. (2015). Corporate Social Responsibility Practices in Listed Companies. Journal of Management Research,7(1), 139-149.

107. Yin, J. and Wang, S. (2017). The effects of corporate environmental disclosure on environmental innovation from stakeholder perspectives. Applied Economics, 50(8), 905-919. 108. Yusoff, H., Othman, R. and Yatim, N. (2013). Environmental Reporting Practices in Malaysia and Australia. The Journal of Applied Business Research, 29(6), 1717-1726.

109. Yusoff, H. and Darus, F. (2014). Mitigation of Climate Change and Prevention of Pollution Activities: Environmental Disclosure Practice in Islamic Financial Institutions. Procedia - Social and Behavioral Sciences, 145, 195-203.

110. Yusoff, H. and Lehman, G. (2008). International Differences on Corporate Environmental Accounting Developments: A Comparison between Malaysia and Australia. Accounting and Finance in Transition. 4, Greenwich University Press, 92-124

111. Yusoff, H. and Lehman, G. (2009). Corporate Environmental Reporting through the Lens of Semiotics. Asian Review of Accounting, 17 (3), 226-246.

112. Zeghal, D., \& Ahmed, S. A. (1990). Comparison of Social Responsibility Information Disclosure Media Used by Canadian Firms. Accounting, Auditing \& Accountability Journal, 3(1), 38-53. 